https://doi.org/10.21122/2227-1031-2020-19-1-76-84

UDC 349

\title{
How to Make the Charging Simple, Convenient and Efficient
}

\author{
W. Cheng ${ }^{1}$, Y. Wang ${ }^{1)}$ \\ ${ }^{1)}$ Beijing Matrix Mobility Technology Co., Ltd (Beijing, People's Republic of China) \\ (C) Белорусский национальный технический университет, 2020 \\ Belarusian National Technical University, 2020
}

\begin{abstract}
With the large-scale application of electric vehicles (EV) in the world and also in China, the contradiction between the EV and charging stations has become more and more prominent. People always cannot easily find the charging stations or when they find them finally found they do not work. To connect the vehicle, charging station/pile and end-users for making the charging simple, convenient, efficient and visible is becoming very important. People need a platform to tell them where, when and how to charge for their EV. Matrix Mobility is focusing on realizing this comprehensive charging solution together with OEM, charging point operator (CPO), electric power company and parking lots by using big data analysis. Matrix Mobility installs the charging solution into the car unit before cars go off production line and meanwhile integrates the same function into OEM's own APP with opening API to help end-users increase their charging experience.
\end{abstract}

Keywords: e-mobility, charging solution, connected charging system, electric vehicle, CPO, big data

For citation: Cheng W., Wang Y. (2020) How to Make the Charging Simple, Convenient and Efficient. Science and Technique. 19 (1), 76-84. https://doi.org/10.21122/2227-1031-2020-19-1-76-84

\section{Как сделать зарядку электромобиля простой, удобной и эффективной}

\author{
У. Ченг ${ }^{1)}$, И. Ван ${ }^{1)}$ \\ ${ }^{1)}$ Пекинская матрикс мобилити технолоджи компания, Лимитид (Пекин, Китайская Народная Республика)
}

Реферат. По причине широкого использования электромобилей во всем мире, а также в Китае все более актуальной становится решение проблемы электромобилей и зарядных станций. В настоящее время не всегда легко найти зарядные станции, а когда, наконец, находишь их, то обнаруживаешь, что они не работают. Поэтому для того, чтобы сделать процесс зарядки простым, удобным, эффективным и заметным, необходимо обеспечить взаимодействие между транспортным средством, зарядной станцией и потребителем. Потребитель нуждается в информационной платформе, которая предоставит ему ответы на следующие вопросы: где, когда и сколько будет стоить зарядка электромобиля? Используя результаты анализа огромного количества данных, компания «Матрикс мобилити» прилагает усилия для решения вопросов зарядки транспортных средств с помощью использования соответствующего программного обеспечения, а также четкого взаимодействия с оператором пункта зарядки, энергетической компанией и администрацией паркингов. «Матрикс мобилити» предлагает выполнять зарядку транспортного средства до того, как оно сойдет с производственной линии. В то же время решение этой задачи интегрируется в приложение программного обеспечения с действующим прикладным программным интерфейсом, чтобы повысить качество процесса зарядки для потребителя.

Ключевые слова: использование электромобиля, решение зарядного процесса, подключенная зарядная система, электромобиль, оператор пункта зарядки, большие объемы данных

Для цитирования: Ченг, У. Как сделать зарядку электромобиля простой, удобной и эффективной / У. Ченг, И. Ван // Наука и техника. 2020. Т. 19, № 1. С. 76-84. https://doi.org/10.21122/2227-1031-2020-19-1-76-84

\author{
Адрес для переписки \\ Ченг Уильям \\ Пекинская матрикс мобилити технолоджи компания, Лимитид \\ Навинфо Плаза, Пекин роуд, район Хайдьян, \\ г. Пекин, Китайская Народная Республика \\ Тел.: +86 185 15-27-88-08 \\ william.cheng@navinfo.com
}

\author{
Address for correspondence \\ Cheng William \\ Beijing Matrix Mobility Technology Co., Ltd \\ Navinfo Plaza, Beijing Road, Haidian District, \\ Beijing, People's Republic of China \\ Tel.: +86 185 15-27-88-08 \\ william.cheng@navinfo.com
}




\section{Introduction}

Environmental pollution is becoming a headache for the entire world. Global temperature increasing, greenhouse gases, air pollution and acid raining are only part of those negative phenomenons. And between all different contributors to the pollution, the vehicle emission is the primary cause. Switch from traditional engines to electric vehicles is the main effective way to reduce the pollution. This demand leads to the growing application of electric vehicle (EV) and plug-in hybrid electric vehicle (PHEV) technologies because of their reduced fuel usage and greenhouse emissions, and this is also accepted worldwide. While current charging experience for end-users are still not good, for example:

a) bad charging time - it takes 1-3 hours to fully charge the vehicle comparing to $1-3$ minutes for fuel adding;

b) bad charging infrastructure - it's not easy to find a charging station when you need it, the distribution density is too low to charge;

c) bad charging system - it takes long time for end-users to start charging successfully and have to install too many APPs due to every CPO has their own system. And even worse is that those systems are not good;

d) bad payment system - not convenient for end-user to pay via credit card or back account, it takes too many fussy processes to successfully finish payment;

e) bad information - nor accurate information about charging points, it happens when end-user find a charging point after long time looking for and finally see a charging point, while when he goes for charging found out it was not usable due to damage or not under operation;

f) bad surrounding - charging points are not aligned with parking lots, the charging area can not park which will increase the complaint from end-users.

To stimulate the usage of EV and PHEV, the most important way is to let the end-users feel comfortable with the electric vehicles, which means those vehicles should get charged as simple and convenient as traditional vehicles. The best way to realize it is to work out a comprehensive charging solution together with OEM, charging point operator (CPO), fleets, electric power company and parking lots by using big data analysis to improve the quality of charging experience. Take China as example, there are around 3 million EV and PHEV running on the road, but charging is still the most painful point for end users who's using new energy vehicles (NEV including EV and PHEV).

From the following figure (Fig. 1), you can see there are hug amount of demand for electricity 300 billion $\mathrm{kW} \cdot \mathrm{h}$ by 2030 , this requires a very simple and efficient charging solution for the EVs.

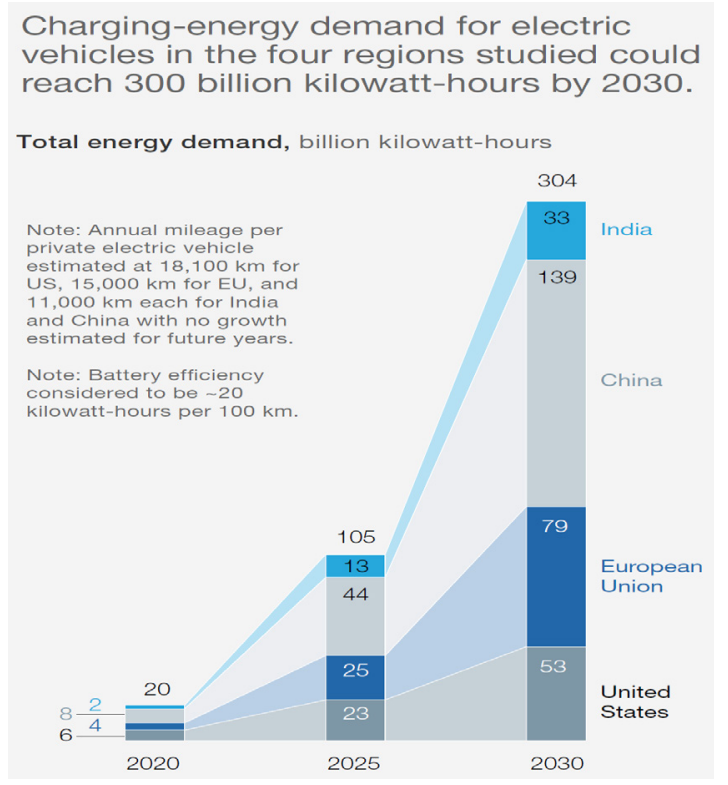

Fig. 1. Electricity demand till 2030

From Fig. 2 you can see the demand of public charging occupies a high portion of overall charging scenarios.

This paper analyzed the high qualified big data of EV running (including battery data from BMS), charging behavior, charging stations, power grid localization, battery usage to work out a charging solution which works better for OEM, CPO (charging point operator), fleets and end users.

\section{Comprehensive charging solution study}

Regarding the EV charging eco-system, we can see there are OEMs, Telematics suppliers, Internet suppliers, Big Data analyzers, Public Charging Station, Wall-box charging, Mobile Charging and the EMSP (e-mobility service provider). The EMSP is the bridge and liaison between the downstream end users and the upstream OEM and CPO. It collects all the data from different parties and analyze, optimize and integrate them to be fit for the parties inside the ecosystem (Fig. 3).

To build the charging platform need to integrate the big data capabilities of Cloud Data Platform, incorporate the data and services of CPOs, 
connect the navigation, charging and peripheral services, and refine operation and management capabilities through Big Data analysis (Fig. 4). Take Matrix Mobility as an example, they have connected more than $97 \%$ of the public charging points with the overall number is about $430 \mathrm{~K}$ charging points together with cloud provider, OEMs like BMW and Daimler and also fleets.

To realize the overall charging solution, we can divide it as 5 phases.

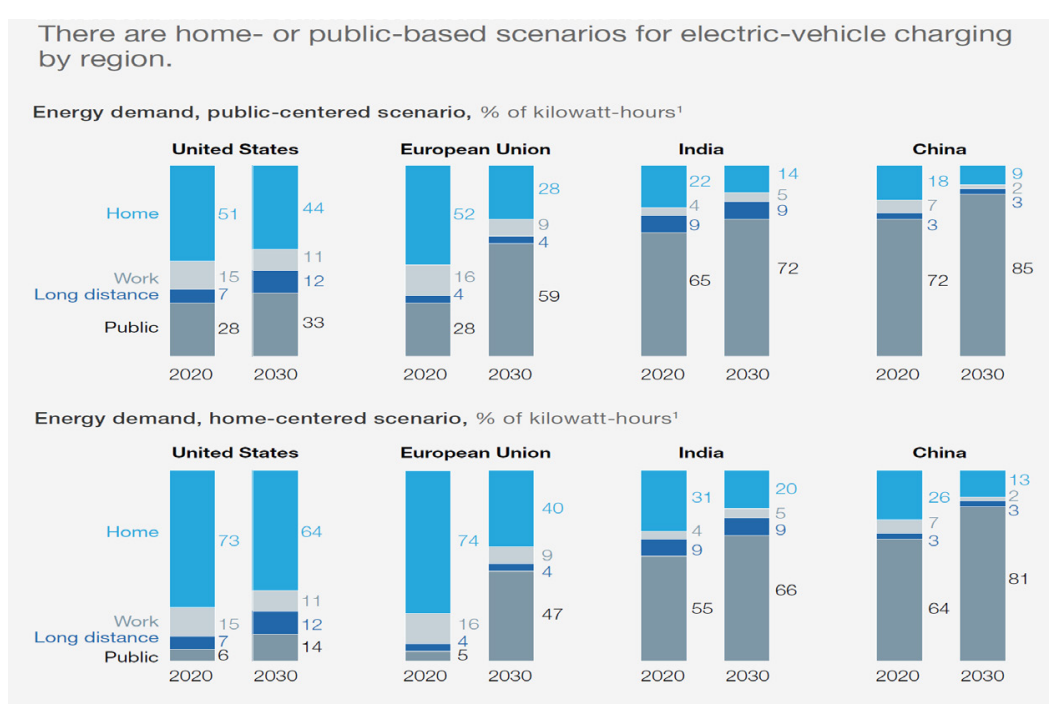

Fig. 2. Charging scenarios by region

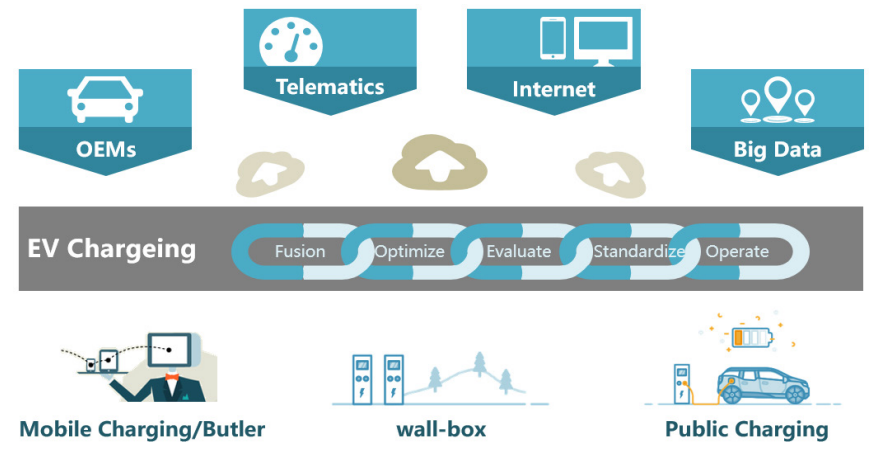

Fig. 3. EV charging ecosystem

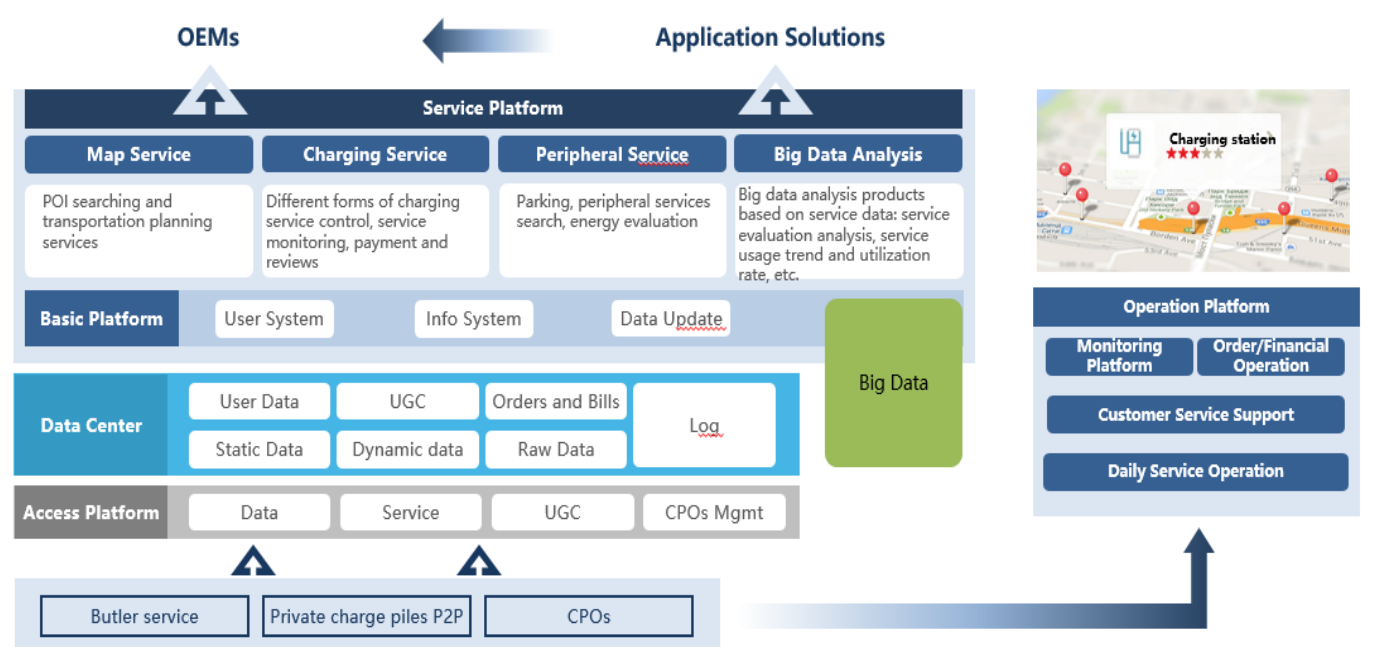

Fig. 4. EV charging platform 
Phase 1. Integrate the charging service into vehicle units that is synchronized to the mobile APP (Fig. 5).

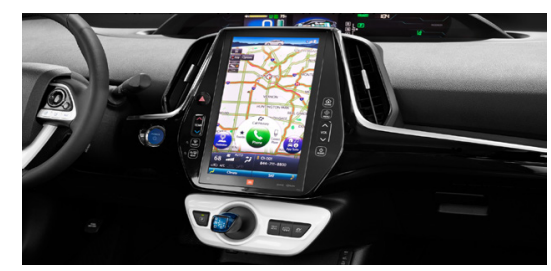

Fig. 5. Vehicle head unit integrated

Phase 2. Integrate the public charging services of $3^{\text {rd }}$ party CPOs, combine with map, navigation and route planning, to provide public charging standard solutions. Since each CPO only has their own network and service, which limits the service number of CPOs for end-users who only use the service from one of those CPOs. It will cause inconvenience and reduce the satisfaction of endusers. To create one platform, which integrated all of the CPOs, is very necessary from of the point of serving end-users better (Fig. 6).

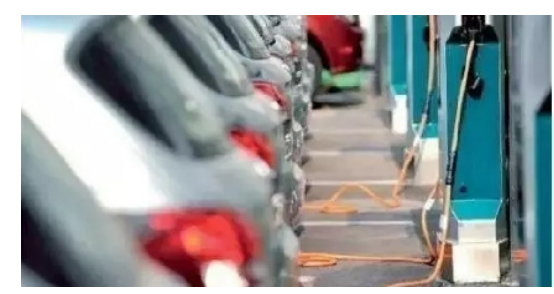

Fig. 6. Combined public CPOs

Phase 3. Aggregate individual charging point resources and build P2P sharing economy through the $3^{\text {rd }}$ party sharing service and charging operation platform (Fig. 7). Upgrade the unconnected individual charging points with $4 \mathrm{G}$-model to connect the static and dynamic data to the data center, then share the individual points to public who need to charge. From the statistics we can see that the number of individual charging points are much higher than public CPOs, which means if we can share them, the end-users will have much more choice for charging.

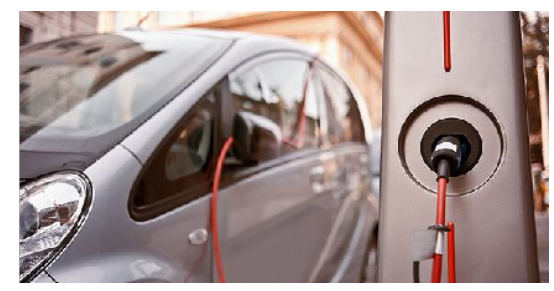

Fig. 7. Individual charging point
Phase 4. Integrate the $3^{\text {rd }}$ party services of the butler, providing high-level butler charging services covering the core cities of the whole country. E.g. parking and charging for customers (Fig. 8), customer can stop and go for their own arrangement, when he/she comes back the vehicle has been charged.

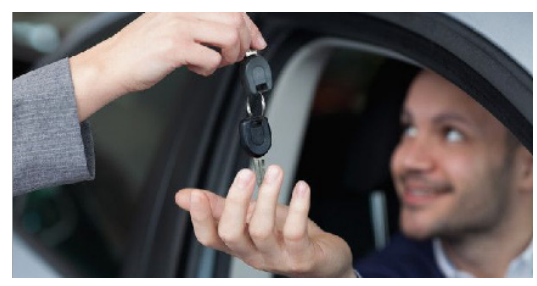

Fig. 8. Parking and charging for cusotmer

Phase 5. Integrate the resources of mobile charging service operators to achieve services such as mobile charging or charging rescue when emergency happens (Fig. 9). This is also one of the main way for reusing the vehicle battery after several years usage in the vehicle. It is called 'cascade utilization' of battery.

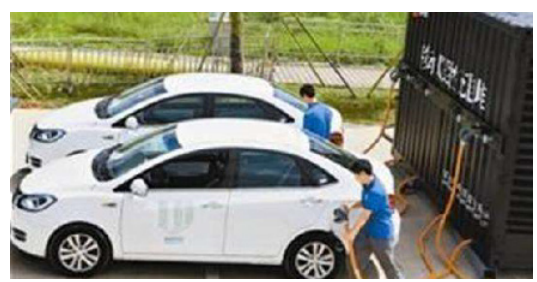

Fig. 9. Movable charging station

Phase 6. Provide charging point operation management platform for exclusive charging station, small charging pile operators, personal charging piles as operation trusteeship support (Fig. 10). Those charging methods need an efficient connected platform to manage all charging points for operators to reduce the cost of management and maintanence.

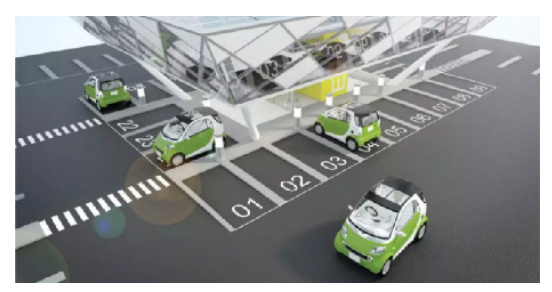

Fig. 10. Exclusive charging station

Supporting above phases, we need to collect and fuse data from map provider (Fig. 11), CPOs and OEMs, store them at cloud platform, do analysis and send them to customers with different applications including static and dynamic data of CPOs. 


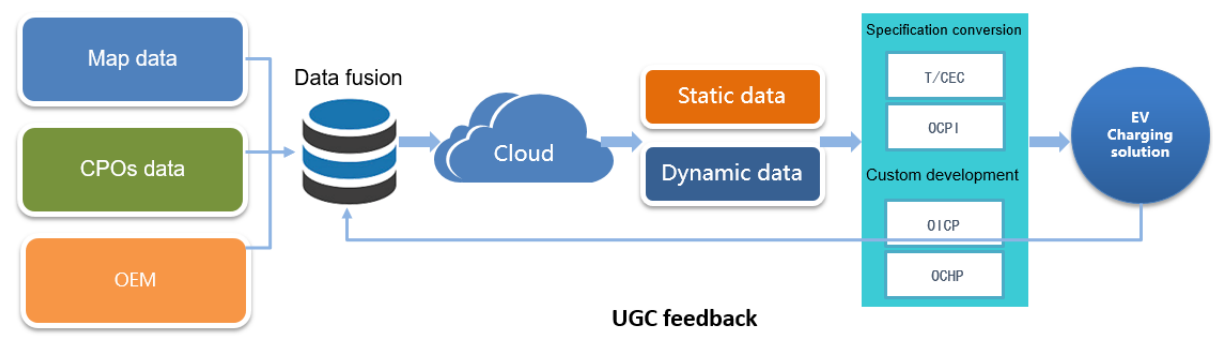

Fig. 11. Framework of data

Among all the different data, CPO data is the base and foundation for an EMSP to provide qualified service to end-users (Fig. 12). In order to ensure the data you provide is qualified, EMSP need to do field check after they get data from CPOs due to the data from CPOs sometimes are not so accurate, for both static and dynamic information. In addition, those data check job should be updated real time to make sure it is the freshest data.

With the integration of many CPOs' charging service, EMSP can provide many convenient services to end users (Fig. 13). Such as:

- financial convenience - help OEM do financial settlement with CPO including payment, prepayment and the invoice process;

- risk management - set the security and risk control of the payment process, and also predict the cost of charging;

- flexible payment - support pre-pay and postpay mode and provide marketing promotion platform to support packages, coupons, etc.;

- multi-brand support - integrate CPOs in the platform for the end users have the right to choose different service from different CPOs.

To ensure the charging process be efficient, we need to do following jobs (Fig. 14):
- CPO Identification: encoding information transfers to the platform through scanning QR code, according to the rules of encoding information, the platform automatically matches the different CPOs and establishes the connection;

- charging point data check. After establishing the connection, the platform will acquire the information of the corresponding charging point, automatically detect whether the device can be controlled or not. If the control can be realized, the dynamic and static information of the device will be acquired to feedback the user to verify the equipment information;

- charging Start/Stop: after the user sends the start/stop instruction, the EMSP transmits the instruction to the CPO platform, receives the feedback of the execution of the instruction, CPO platform will remote the charging point and synchronously starts/stops the state to the user;

- charging process monitoring: in the charging process, continuous docking between EMSP and $\mathrm{CPO}$ platform, receiving or actively grabbing dynamic charging information feedback from $\mathrm{CPO}$ platform and synchronizing it to user.

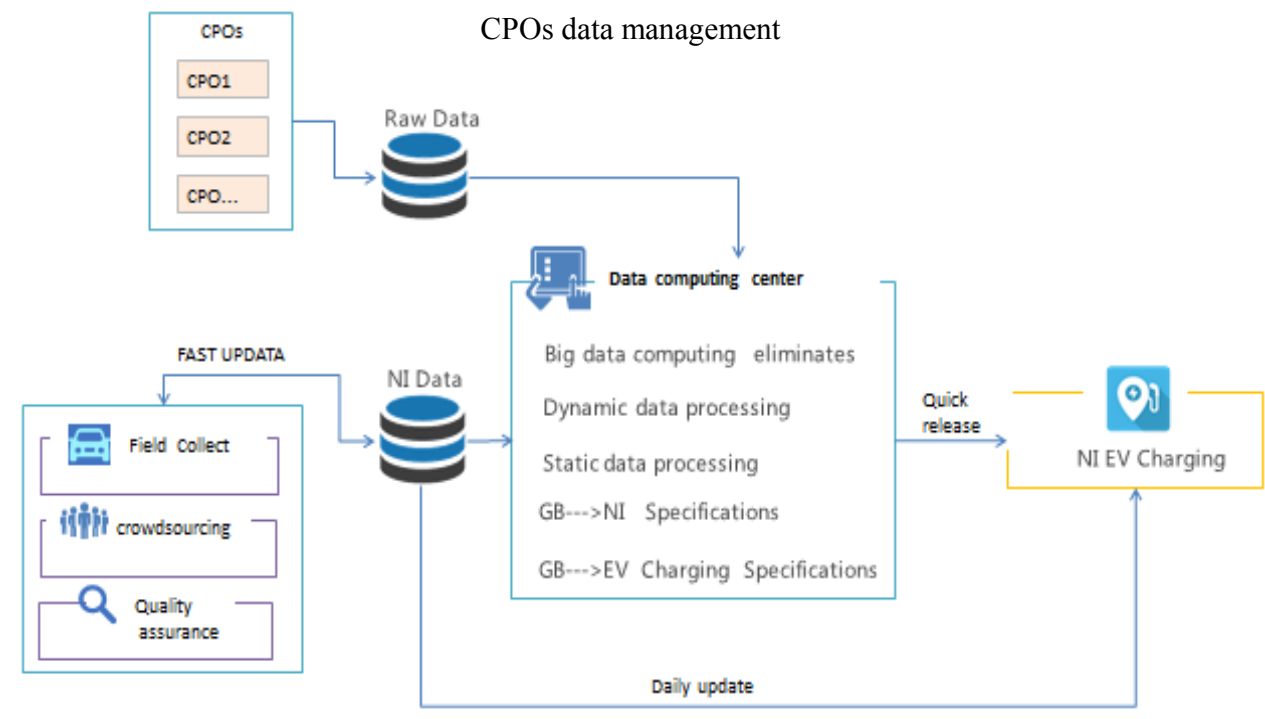

Fig. 12. CPO data management 


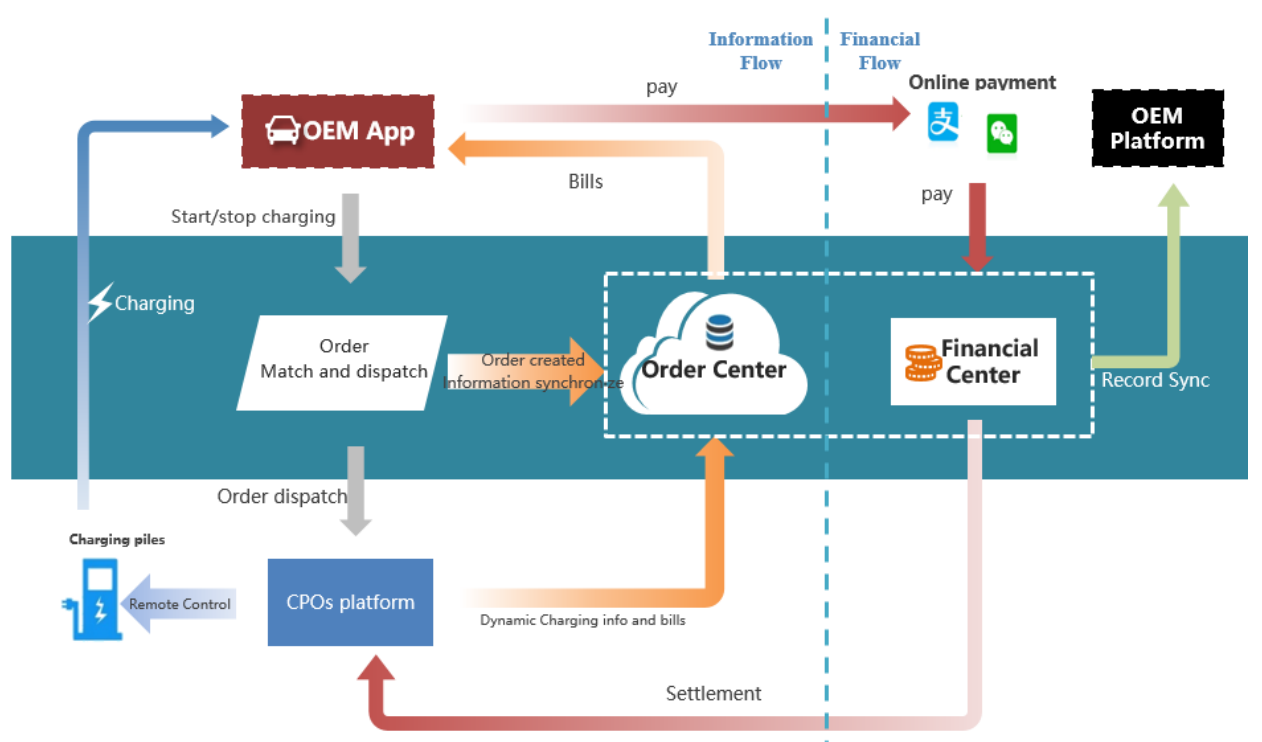

Fig. 13. EMSP order process

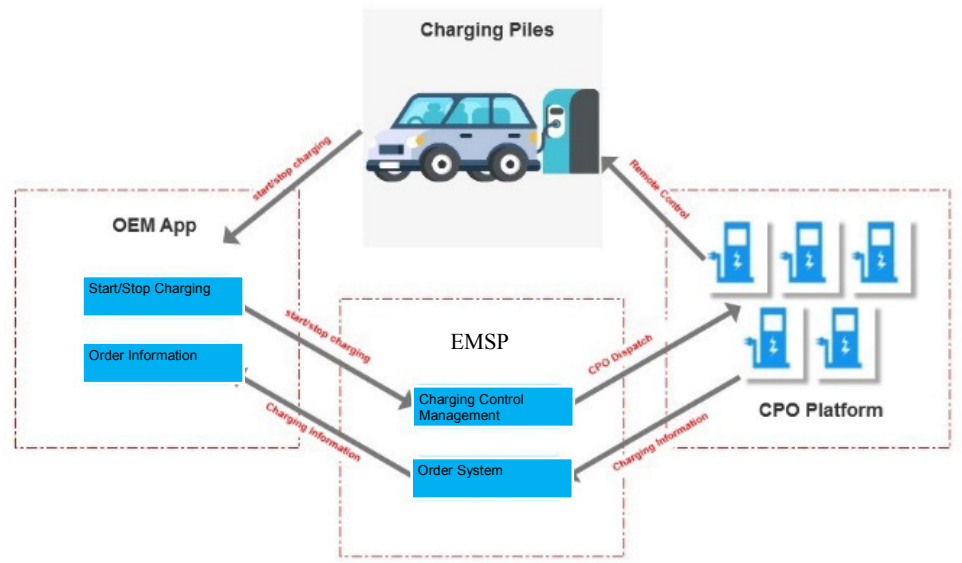

Fig. 14. Charging synchronizing process

Regarding the charging payment process (Fig. 15), users without unpaid orders could send charging control command through the front-end of OEM to start charging process.

After the user sends the charging stop order, the bills generated by CPO platform are first pushed to the backend of EMSP, and then pushed to the frontend of OEM.

Users can choose the appropriate payment method (Wallet/ WeChat/ Alipay/ Credit card, etc.) to pay their charging bills with different tariffs may include time-based fees, energy-based fees which should not exceed the CPO public prices or flat rates. The financial center will record the payment details of all the bills and generate the reconciliation statement.

Online payment service platform supports a variety of flexible transaction payment methods, including Pre-pay, Post-pay, Package, Coupons, etc. (Fig. 16).

Pre-pay and Post-pay are the supporting functions of standard charging service platform. The realization of Storage card, Packages and Coupons can be realized by building a marketing promotion platform parallel to charging service platform.

We recommend standard payment schemes including Pre-pay and Post-pay.

In case there is bad debt happens, the system will limit the service to users. Once the direct-pay mode failed or pre-payment is not enough, users have to finish all payments before opening a new charging order. To avoid or reduce the lost due to above situation, a $3^{\text {rd }}$ party financial monitoring platform can be introduced into the process such as Alipay or Paypal.

In order to provide more support for OEM's marketing activities after SOP, EMSP need to 
provide a marketing platform independent from the basic charging service platform (Fig. 17). These two platforms act different responsibilities and provide many support to each other.

The purpose of the marketing promotion platform is to encourage the users to like using EVs and charging for EVs, to do from providing free charging to route planning and usage reports, users will love to travel with EVs (Fig. 18).

In order to make the process and status more visible, the charging platform can provide customers with behavior analysis, service status, financial reports, call center, charging points status, demand prediction, etc. (Fig. 19).

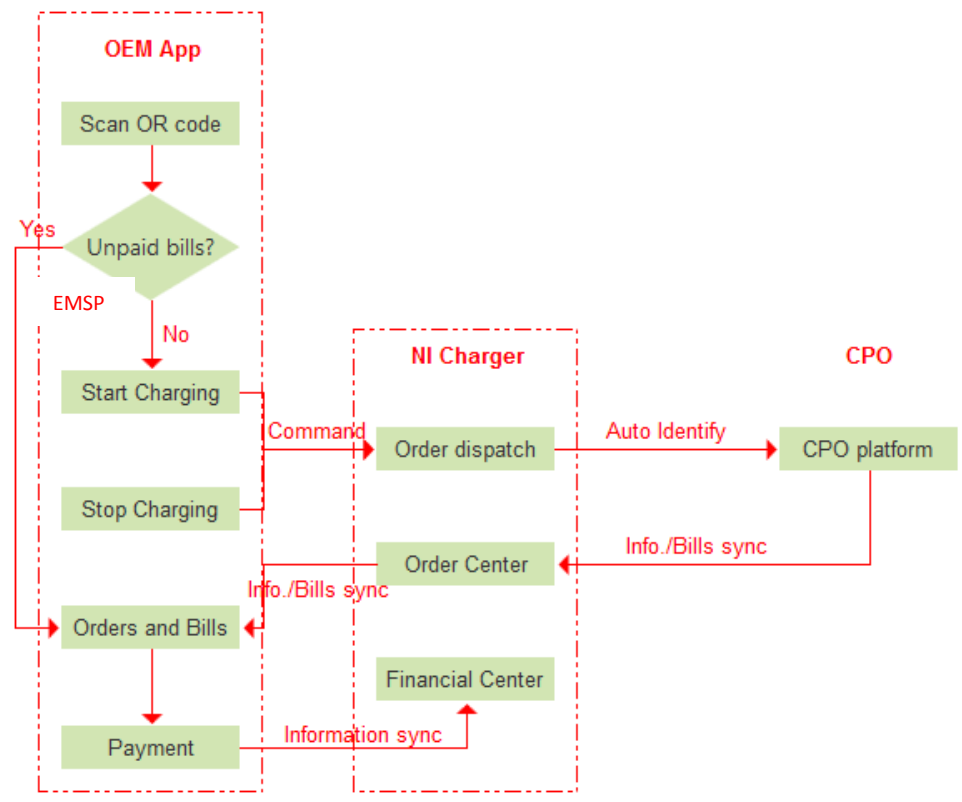

Fig. 15. Payment process

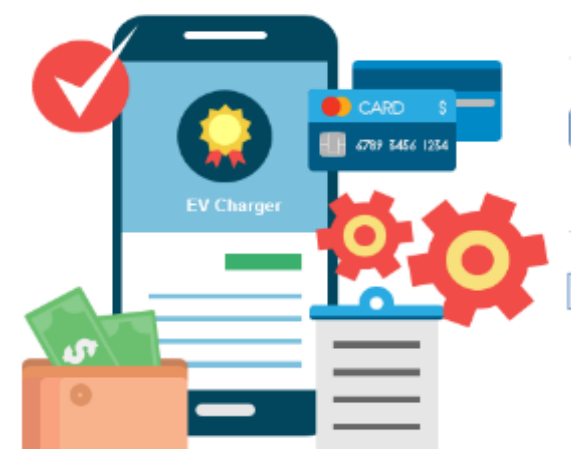

\section{Pre-pay}

Users need to reserve fees. for charging services.

\section{Charging Package}

The platform can define the power consumption and

expiry date of the package.

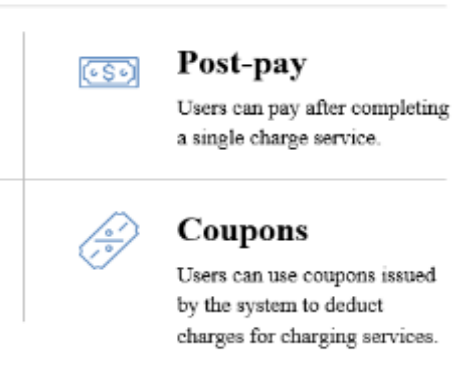

Fig. 16. Payment modes

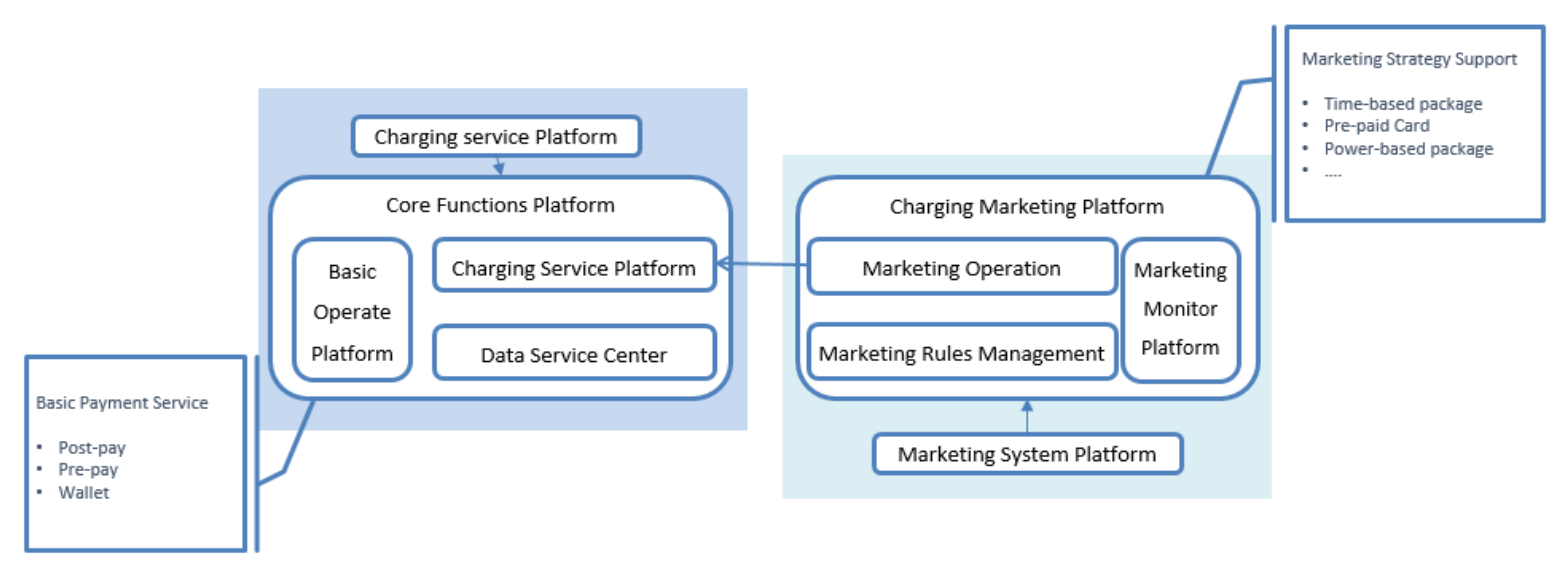

Fig. 17. Interaction of service and marketing platform 


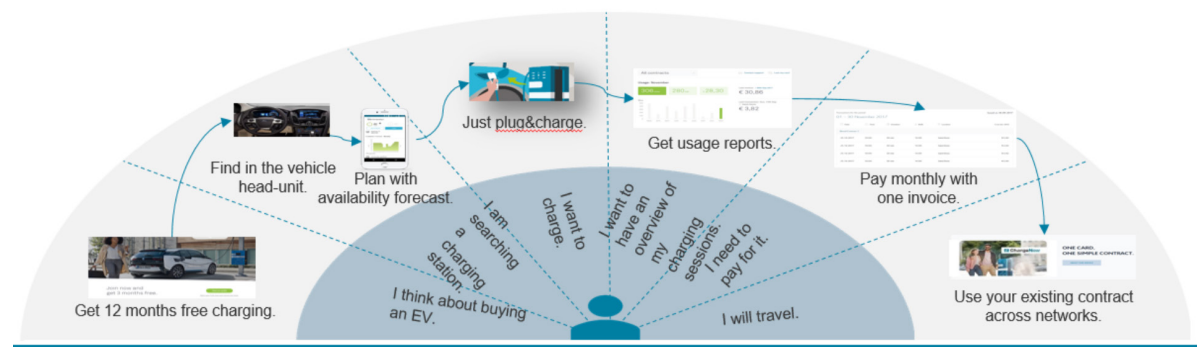

Fig. 18. Charging marketing promotion

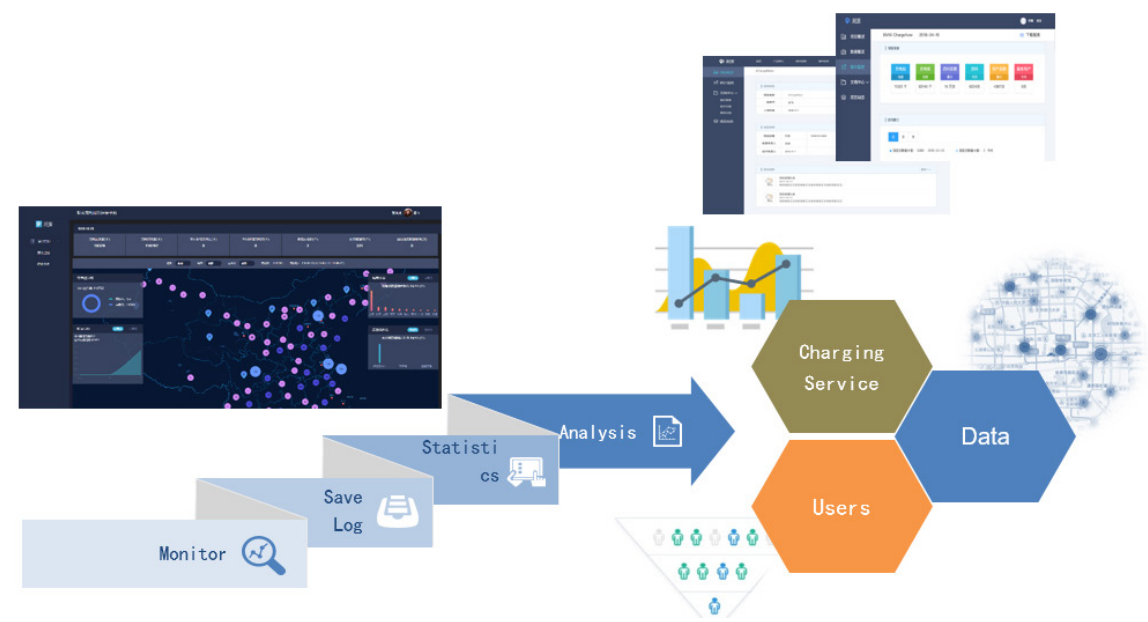

Fig. 19. Visible charging platform

\section{CONCLUSIONS}

1. This paper studied from the overall environmental situation, EV market status, demand, current EV and charging solutions, did analysis based on those data, combined the real demand from endusers, we suggested a comprehensive charging solution which integrates OEMs, CPOs, Power Grids and also users. This charging solution we call it EMSP, it can not only provide service to OEMs, CPOs, Power Grids, but also can serve to end-users from indicating where is the charging point, how to charge to the payment of charging - one stop charging solution. It can also keep the solution as a visible platform for all different users with providing them various reports including charging history, behaviors, demand prediction, cost analysis and prediction, etc.

2. We believe this charging solution will bring a big benefit to the whole EV industry, to accelerate the development of industry, to make people love to drive EVs, to reduce the emission of vehicles and to make our world much cleaner and more beautiful.

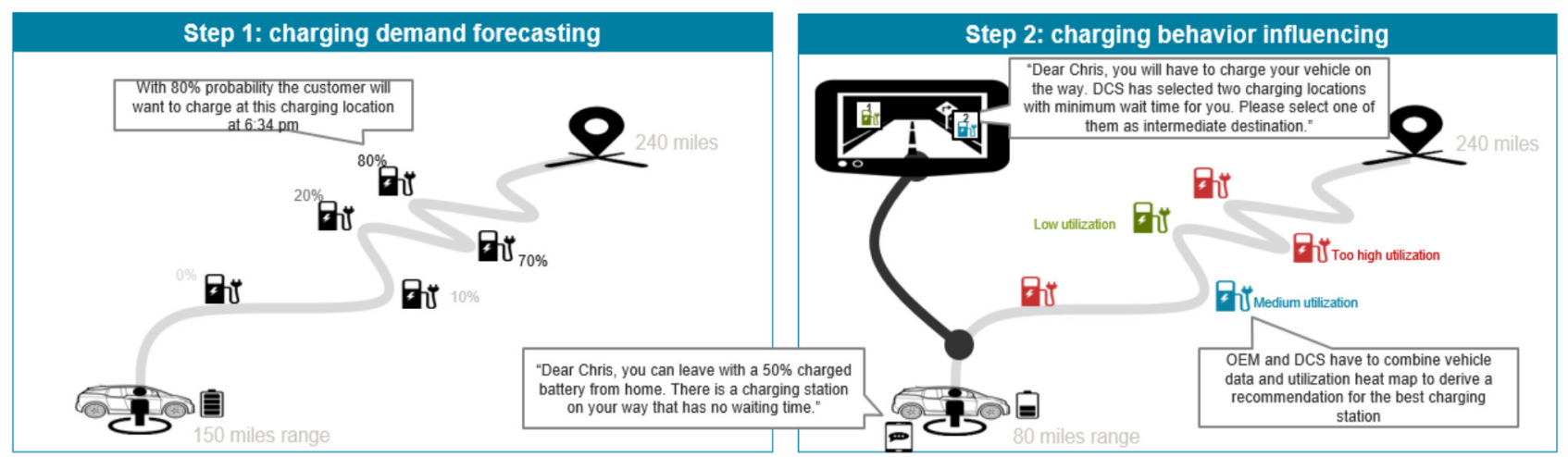

Fig. 20. Make EV running on the way 


\section{REFERENCES}

1. Ying Wang, William Cheng (2018) Introduction of Beijing Matrix Mobility Comprehensive Charging Solution. Beijing, Matrix Mobility.

2. Emadi A., Ehsani M., Miller J. M. (2003) Vehicular Electric Power Systems: Land, Sea, Air, and Space Vehicles. New York, Marcel Dekker. https://doi.org/10.1201/9780 203913468.

3. Larminieand J., Lowry J. (2003) Electric Vehicle Technology Explained. New York, Wiley.

4. Saber A. Y., Venayagamoorthy G. K. (2015) One Million Plug-in Electric Vehicles on the Road by 2015. $12^{\text {th }}$ International IEEE Conference on Intelligent Transportation Systems, 141-147. https://doi.org/10.1109/itsc.2009.5309691.

5. Massachusetts Division Energy Resources, MA (Sep. 2000) Installation Guide for Electric Vehicle Charging Equipment.

6. CHAdeMO Association (2011). Desirable Characteristics of Public Quick Charger. Tokyo Electric Power Company, Tokyo, Japan.

7. Haghbin S., Khan K., Lundmark S., Alak"ula M., Carlson O., Leksell M., Wallmark O. (2010) Integrated Chargers for EV's and PHEV's: Examples and New Solutions. The XIX International Conference on Electrical Machines - ICEM 2010, 1-6. https://doi.org/10.1109/icelmach. 2010.5608152.

8. Musavi F., Edington M., Eberle W., Dunford W. G. (2012) Evaluation and Efficiency Comparison of Front end AC-DC Plug-in Hybrid Charger Topologies. IEEE Trans. Smart Grid, 3 (1), 413-421. https://doi.org/10.1109/tsg. 2011. 2166413.

9. SAE International (2011, Sep. 8) SAE's J1772 “Combo Connector" for AC and DC Charging Advances with IEEE's Help. Available at: http://www.sae.org/mags/aei/10128.

10. Mathoy A. (2008) Definition and Implementation of a Global EV Charging Infrastructure. Final Rep. Brusa Elektronik, Sennwald, Switzerland, 2008. Available at: https://www.yumpu.com/en/document/view/39489467/def inition-and-implementation-of-a-global-ev-park-charge.
11. Su W., Zeng W., Chow M. Y. (2012) A Digital Testbed for a PHEV/PEV Enabled Parking Lot in a Smart Grid Environment. 2012 IEEE PES Innovative Smart Grid Technologies (ISGT), 1-7. https://doi.org/10.1109/isgt. 2012.6175581.

12. Fasugba M. A., Krein P. T. (2011) Cost Benefits and Vehicle-to-Grid Regulation Services of Unidirectional Charging of Electric Vehicles. IEEE Energy Conversion Congress and Exposition, 827-834. https://doi.org/10.1109/ ecce.2011.6063856.

13. Sortomme E., El-Sharkawi M. (2011) Optimal Charging Strategies for Unidirectional Vehicle-to-Grid. IEEE Trans. Smart Grid, 2 (1), 131-138. https://doi.org/10.1109/tsg. 2010.2090910.

14. De-Sousa L., Bouchez B. (2010) Combined Electric Device for Powering and Charging. Int. Patent WO 2010/ 057892A1.

15. Mi C. Safely Charging EV and PHEV from the Electricity Grid. Dept. Elect. and Comput. Eng., Univ. of MichiganDearborn, Dearborn.

16. Qian K., Zhou C., Allan M., Yuan Y. (2011) Modeling of Load Demand due to EV battery Charging in Distribution Systems. IEEE Transactions on Power Systems, 26 (2), 802-810. https://doi.org/10.1109/tpwrs.2010.2057456.

17. Yang Y., Lin Z., Qin D., Hu M., Yang Y. (2007) Control Strategy and Simulation Study on NiMH Battery Quick Charging for Regenerative Braking of HEV. Journal of Chongqing University (Natural Science Edition), 30 (3), 1-5.

18. Li Z., Sahinoglu Z., Tao Z., Teo K. (2010) Electric Vehicles Network with Nomadic Portable Charging Stations, in Proc. 2010 IEEE $72^{\text {nd }}$ Vehicular Technology Conference - Fall., 1-5. https://doi.org/10.1109/vetecf.2010. 5594437.

19. Chen Q., Sun F., Zhu J. (2004) Modern Electric Vehicle Technology. Beijing, China: Beijing Institute of Technology Press.

Received: 08.10.2019

Accepted: 10.12.2019

Published online: 31.01 .2020 